\title{
Straw Production, Carbon and Ash Content Variations after Ten Cycles of Recurrent Selection in Bread Wheat Grown under Tilled and Non-tilled Soils
}

\author{
R.H. MAICH*, S. HANG and J.A. Di RIENZO \\ Facultad de Ciencias Agropecuarias, Universidad Nacional de Córdoba, Córdoba, Argentina \\ (Received 4 July 2016; Accepted 27 October 2016; \\ Communicated by J. Zhang)
}

\begin{abstract}
The objective of this work was to determine the change for straw production, carbon and ash content in vegetative tissues through ten cycles of recurrent selection in bread wheat, evaluated under tilled (CT) and non-tilled (NT) soils. Twenty-four wheat genotypes, four for each one of the $0,2,4,6,8$ and 10 cycles of recurrent selection (RS), were used in this study. Experiments were established during two successive seasons. Ash content was expressed on dry mass basis. To estimate the carbon content, we based our calculation on the assumption that organic matter is $50 \%$ carbon. Straw dry weight was measured. For each trait, a linear mixed model (regression) was fitted to the experimental data. In response to the number of selection cycles, the ash content percentage increased under CT and decreased under NT. Carbon content decreases under CT, but increases under NT. The sequestered straw carbon and the straw production significantly decrease under $\mathrm{CT}$ meanwhile there was no change under NT. The observed increase for straw ash content would be related to the highest rate of transpiration in the more advanced recurrent selection cycles. Consistent with these results, the percentage of straw carbon content decreased because of the mobilization of reserves from the stems and leaves to the grains.
\end{abstract}

Keywords: mineral straw content, carbon straw content, soil management, wheat breading

\section{Introduction}

Mechanism of mineral accumulation in vegetative tissues may be explained, in part, through the passive transport of minerals driven by transpiration (Cabrera-Bosquet et al. 2009). So, higher transpiration rate increases the amount of passively transported minerals in the leaves (Zhu et al. 2008). In this context, Merah et al. (2001) hypothesized that lower transpiration efficiency (TE), may result in higher dry matter partitioning to grain; while Monneveux et al. (2006) stated that breeding for high carbon isotope discrimination $(\Delta)$ in grain at maturity would lead, under water stress conditions, to higher stomatal conductance, lower TE and higher grain yield. Given the cost and technical skills required for $\Delta$ assessment, a simpler chemical determination, ash (mineral) content, was proposed as a surrogate for $\Delta$ (Araus et al. 1998; Merah et al. 1999). Masle et al. (1992) found that

*Corresponding author; E-mail: rimaich@agro.unc.edu.ar 
genotypes with low transpiration efficiency (high $\Delta$ ) had higher ash content in leaf dry matter. Moreover, a positive correlation was found between leaf ash content and grain yield under drought or residual soil moisture stress (Misra et al. 2006). Consequently, higher values of stomatal conductance (indicator of transpirative gas-exchange activity) and ash content on vegetative organs should be positive related with grain yield. Reports from several authors support this hypothesis: Araus et al. (1998); Merah et al. (1999); Araus et al. (2001) and Monneveux et al. (2004a). In this context, comparisons of materials derived from successive cycles of recurrent selection can throw an interesting light on the evolutionary trend in morph-physiological and agronomical characteristics.

From an agronomical point of view, Gajri et al. (1992) observed that conventional tillage (CT) increased the transpiration rate, and simultaneously the grain yield, compared to non-tillage (NT). While the adoption of NT brought the benefit of increased water storage in the soil, a drawback is the reduced availability of inorganic nitrogen (López-Bellido and López-Bellido 2001). Moreover, under NT an increase in stored water does not imply an increased use of it (Baumhardt and Jones 2002). In this line, Fabrizzi et al. (2005) shown that a greater soil water content at harvest was the result of a lower crop growth due to nitrogen deficiency. However, the agronomical performance of wheat under NT has been related to water rather than nitrogen availability (O'Leary and Connor 1997; Fuentes et al. 2003). Finally, an unfavorable crop response to no-tillage may be the consequence a lower crop water use during the stem elongation stage (López and Arrúe 1997).

The objective of this work was to determine the changes in straw production, carbon and ash content in vegetative tissues, through ten cycles of recurrent selection in bread wheat evaluated under tilled and non-tilled soils.

\section{Materials and Methods}

\section{Plant material}

Twenty-four wheat genotypes (Triticum aestivum L.), four for each one of the 0, 2, 4, 6, 8 and 10 cycles of recurrent selection (RS), were used in this study. The twenty-four genotypes did not highly differ in phenology. The development of the base population was described by Maich and Di Rienzo (2014).

\section{Site and crop management}

Trials were carried out under rain-fed conditions at the Campo Escuela de la Facultad de Ciencias Agropecuarias (Universidad Nacional de Córdoba), Córdoba (31 ${ }^{\circ} 29^{\prime} \mathrm{S} ; 6^{\circ} 00^{\prime}$ $\mathrm{W})$ in the central semiarid region of Argentina, with a characteristic Enthic Haplustol soil (organic matter content 2.50\%, pH 6.3) with a soil depth of $0.60 \mathrm{~m}$. The soil is rich in phosphorus and has a relatively high water-holding capacity (around 20\%). Experiments were established during two successive seasons (2011 and 2012). Sowing was made on 10th and 8th of May 2011 and 2012, respectively. Anthesis occurred in September and maturity at the end of October in all 2 yrs. The twenty-four genotypes were evaluated 
under conventional and non-tillage systems in two fields, next to each other, located in the same site of the selection program. One row plots $5 \mathrm{~m}$ long spaced $0.20 \mathrm{~m}$ at a seeding rate of 250 viable seeds by square meter were used. Because of restriction to randomization, imposed by the tillage practices, two replicates in complete blocks where allocated within each field. Complete weed control was made by hand weeding.

\section{Climatic condition}

Residual soil moisture stress is the most common type of water stress experienced by rain-fed wheat in this zone leading to post-anthesis water stress. The first year (2011) was characterized by a low total rainfall $(141.5 \mathrm{~mm})$, with a strong water deficit occurring at anthesis. The second year (2012), by contrast, was wetter $(236.5 \mathrm{~mm})$. Volumetric soil water content was determined at sowing and at harvest. Cumulated evapotranspiration during the growth cycle was $373.5 \mathrm{~mm}$ (2011) and $347.5 \mathrm{~mm}$ (2012).

\section{Ash content}

For each genotype at maturity vegetative tissues (referred to as straw, a mixture of stems, leaf blades and sheaths) were ground in a fine powder. The basal parts of plants, $5-\mathrm{cm}$ length above the joint between root and stem, were used. Ash content was determined using the AACC method 08-01 (American Association of Cereal Chemists 1995). Approximately $2 \mathrm{~g}$ of dry mass was placed in pre-weighed porcelain crucibles and incinerated at $575^{\circ} \mathrm{C}$ for $16 \mathrm{~h}$ (until light grey ash was obtained). Ash content (\%) was expressed on dry mass basis. Two measurements were done for each sample.

\section{Carbon content}

The method used to estimate organic matter is based on the principle of weight loss-onignition (WLOI), where the mass lost on heating a dried sample to its ashing temperature is assumed to be organic matter. To estimate the carbon content, we based our calculation on the assumption that organic matter is 50\% carbon (Pribyl 2010).

\section{Straw dry weight}

At maturity, straw production was recorded in each plot and dried in a forced-air drier at $80^{\circ} \mathrm{C}$ for at least $48 \mathrm{~h}$. Dry weight was measured $\left(\mathrm{g} / \mathrm{m}^{2}\right)$.

\section{Statistical analysis}

For each trait, a linear mixed model (regression) was fitted to the experimental data. The fixed terms of the model included the tillage factor (conventional tillage - non-tillage), the number of recurrent selection cycles as a covariable, and their interaction. This way of specifying the fixed part of the model implies to fit two regression lines: one for each 
tillage practice. The random terms included the effects of year, blocks within year-tillage practice, family and the random interactions among year and fixed terms of the model. A significance level of 5\% was used to interpret results. Statistical calculations were performed by InfoStat statistical software (Di Rienzo et al. 2014).

\section{Results}

The regression line of ash content percentage on the number of selection cycles shows a dependency with tillage practices $(p=0.0012)$ (Fig. 1A). Difference on ash content at the beginning of the selection program $\left(\mathrm{C}_{0}\right.$ or base population) was not significant. Meanwhile, the ash percentage increased under $\mathrm{CT}$, it decreased under NT in response to the number of selection cycles.

Although no difference in carbon content was found at the beginning of the selection program, the regression line slope of carbon content percentage on the number of recurrent-selection cycles depends on tillage practices $(p=0.0012)$ (Fig. 1B). Carbon content decreases under CT, but increases under NT. However, the increase (NT) and decrease (CT) was, after 10 cycles of RS, of only a half of a percentage point.

The regression line of sequestered straw carbon per unit area $\left(\mathrm{g} / \mathrm{m}^{2}\right)$ on the number of recurrent-selection cycles was related on tillage practices $(p=0.0001)$, but no differences at the beginning of the selection program were found (Fig. 1C). The sequestered straw carbon significantly decreases at a rate of $5 \mathrm{~g} / \mathrm{m}^{2} /$ cycle under CT $(p=0.0092)$ meanwhile there was no change under NT.

(A)

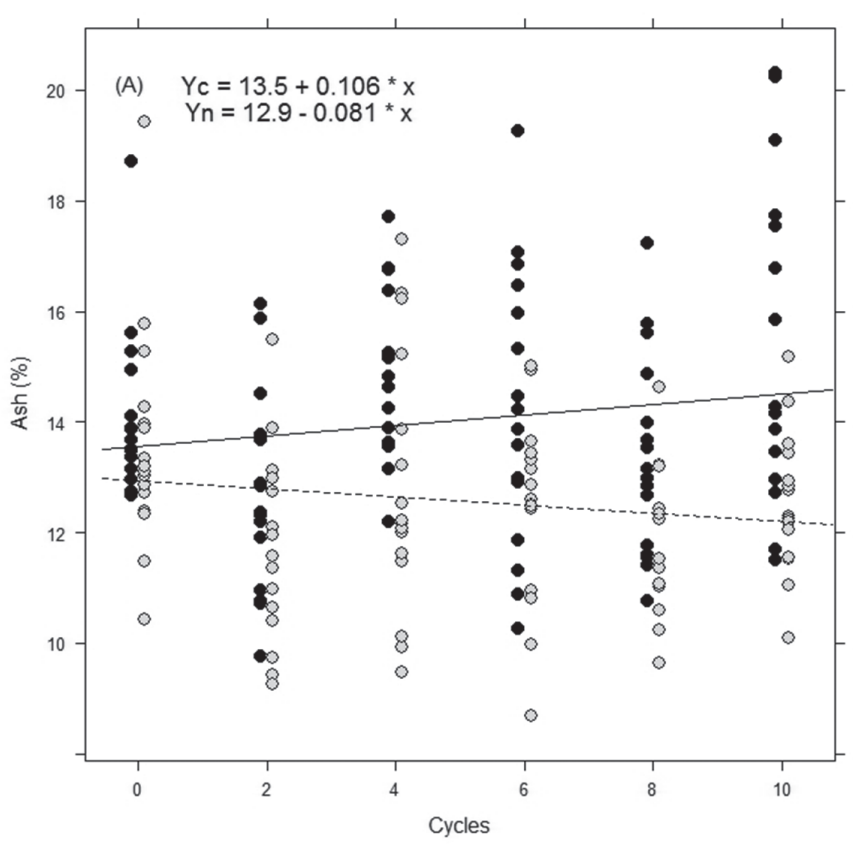


(B)

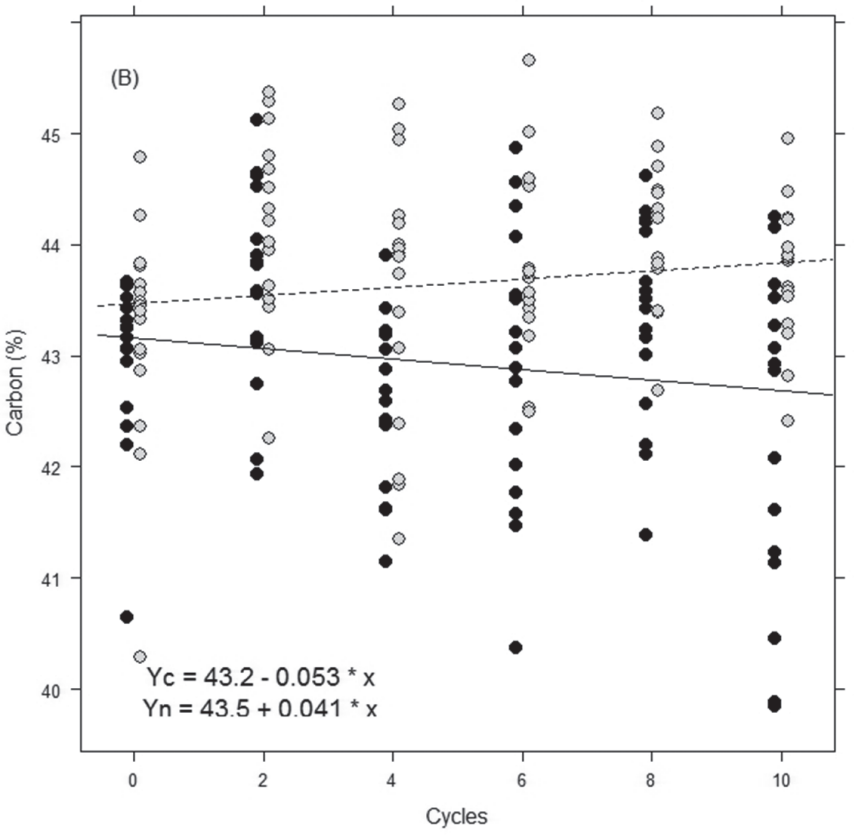

(C)

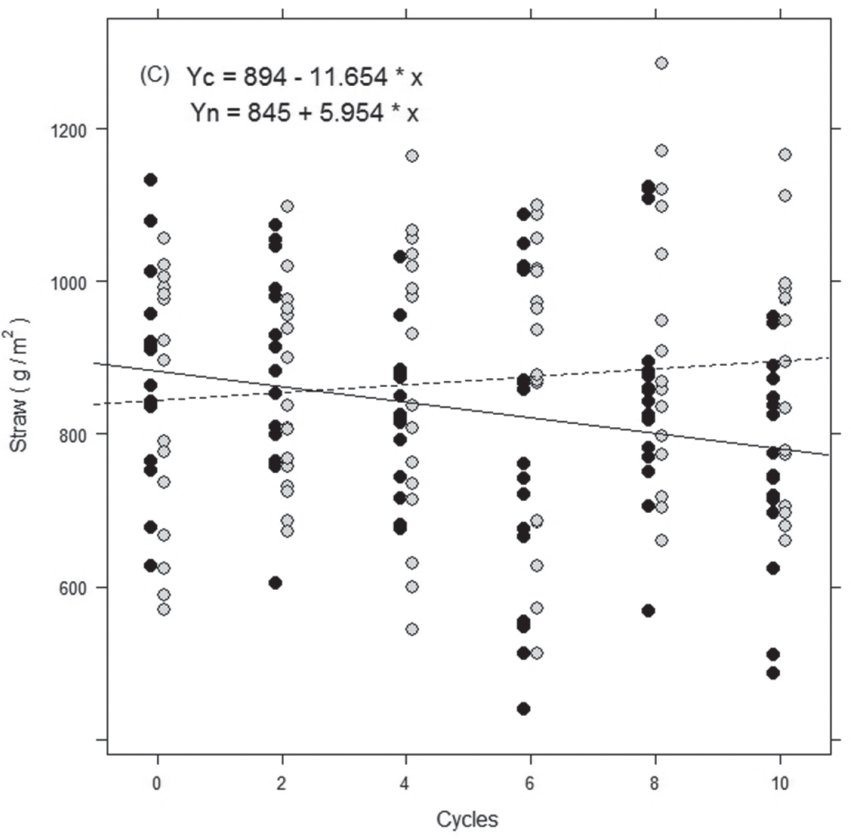

Cereal Research Communications 45, 2017 
(D)

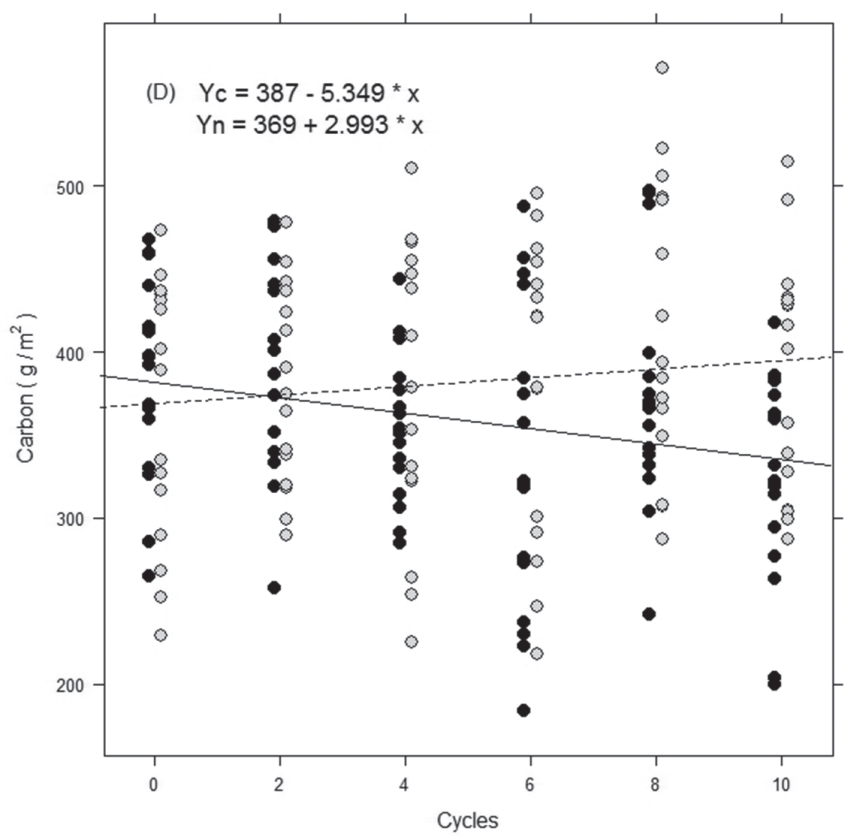

Figure 1. Ash content (\%) (A), carbon content (\%) (B), sequestered carbon per unit area $\left(\mathrm{g} / \mathrm{m}^{2}\right)(\mathrm{C})$ and straw production per unit area $\left(\mathrm{g} / \mathrm{m}^{2}\right)(\mathrm{D})$ versus the number of recurrent-selection cycles. Black and gray dots correspond to conventional tillage and no-tillage, respectively. Solid and dash lines are the regression lines corresponding to conventional tillage and no-tillage, respectively. Yc and $\mathrm{Yn}$ are the estimated linear regression equations for conventional tillage and no-tillage, respectively.

The regression line of straw production per unit area $\left(\mathrm{g} / \mathrm{m}^{2}\right)$ on the number of recurrent-selection cycles depends on tillage practices $(p=0.0003)$ (Fig. 1D). No differences at the beginning of the selection program were found. The straw production significantly decreases at a rate of $12 \mathrm{~g} / \mathrm{m}^{2} /$ cycle under CT meanwhile there was no change under NT.

\section{Discussion}

The observed increase in straw ash content, in correspondence to the number of recurrentselection cycles under CT, can be explained by a correspondent increased rate of transpiration. Misra et al. (2010) and Zhang et al. (2010), concluded that ash content is a good predictor of transpiration. Moreover, Sadras and Connor (1991) established a simple and consistent relationship between harvest index and the fraction of water transpired after anthesis. Monneveux et al. (2004 a-b), showed that higher yields in wheat are accompanied by increased straw ash content; similarly, the improvement for grain yield under CT, found by Maich and Di Rienzo (2014), working on the materials of the same selection program on which this paper is based, are also related with an increase in straw ash content. Not being the water stored in the soil a limiting factor, in the NT soil management 
the reduction in ash content is a direct consequence of a decrease in the transpiration rate correlated with the absence of genetic progress in yield (Maich and Di Rienzo 2014).

Considering that ash content is related to the efficiency of carbon partitioning to the grain (Zhu et al. 2009), the decreased of the percentage of straw carbon content with the succession of cycles of recurrent selection, is the result of the mobilization of reserves from the stems and leaves (source) to the grains (sink). This is in line with the increase of grain yield and harvest index after ten cycles of recurrent selection evaluated under CT, and the no progress in grain production under NT reported by Maich and Di Rienzo (2014). The evidence points to water stress occurred during grain-filling period under the NT system, supported by the following arguments: 1) there was no difference in aerial biomass production between NT and CT (no matters the cycle), 2) the amount of stored water and the $\mathrm{N}$ availability in the soil before sowing for both tillage conditions was the same, and 3) at harvest, the NT soil retained more water than the CT soil (Maich and Di Rienzo 2014). This situation affected negatively NT grain production, confirming what was stated by Blum (1998) regarding the negative effect of water stress during the grain filling period on the mobilization of the stem stored carbohydrates to the grain.

The decline in the amount of sequestered straw carbon per unit area under CT, after ten cycles of recurrent selection, can be explained by the increased export of photo-assimilated to the sink. A positive relationship between harvest index and dry matter mobilization efficiency during grain filling was demonstrated by Zhang et al. (2008). Conversely, the invariability of straw carbon values per unit area, when the material was evaluated under NT, is the result of a straw carbon sequestration capacity but the concomitant inability to mobilize into the grain because of a water deficiency.

Our results showed a decrease in the straw production under CT, and considering that Maich and Di Rienzo (2014) did not observe any progress for aerial biomass production in both CT and NT agronomical practices, the increased capacity of the partitioning aerial biomass to grain yield (harvest index) causes a decrease in the amount of remaining straw. The absence of significant changes under NT for straw production is associated with no changes in harvest index.

In summary, the increased ash and decreased carbon straw content under CT, would be related to the highest rate of transpiration and mobilization of reserves from the stems and leaves to the grains in the more advanced recurrent-selection cycles.

\section{References}

American Association of Cereal Chemists 1995. Approved Methods of the AACC, 9th Edition. AACC Method 08-01. AACC, St Paul, MN, USA.

Araus, J.L., Amaro, T., Casadesús, J., Asbati, A., Nachit, M.M. 1998. Relationships between ash content, carbon isotope discrimination and yield in durum wheat. Functional Plant Biol. 25:835-842.

Araus, J.L., Casadesus, J., Bort, J. 2001. Recent tools for the screening of physiological traits determining yield. In: Reynolds, M.P., Ortiz-Monasterio, J.I., McNab, A. (eds) Application of Physiology in Wheat Breeding, CIMMYT, Mexico. pp. 59-77.

Baumhardt, R.L., Jones, O.R. 2002. Residue management and tillage effects on soil-water storage and grain yield of dryland wheat and sorghum for a clay loam in Texas. Soil and Tillage Res. 68:71-82.

Blum, A. 1998. Improving wheat grain filling under stress by stem reserve mobilization. Euphytica 100:77-83. 
Cabrera-Bosquet, L., Sánchez, C., Araus, J.L. 2009. How yield relates to ash content, $\Delta 13 \mathrm{C}$ and $\Delta 18 \mathrm{O}$ in maize grown under different water regimes. Ann. of Bot. 104:1207-1216.

Di Rienzo, J.A., Casanoves, F., Balzarini, M.G., Gonzalez, L., Tablada, M., Robledo, C.W. InfoStat versión 2014. Grupo InfoStat, FCA, Universidad Nacional de Córdoba, Argentina. URL http://www.infostat.com.ar

Fabrizzi, K.P., García, F.O., Costa, J.L., Picone, L.I. 2005. Soil water dynamics, physical properties and corn and wheat responses to minimum and no-tillage systems in the southern Pampas of Argentina. Soil and Tillage Res. 81:57-69.

Fuentes, J.P., Flury, M., Huggins, D.R., Bezdicek, D.F. 2003. Soil, water and nitrogen dynamics in dryland cropping systems of Washington State, USA. Soil and Tillage Res. 71:33-47.

Gajri, P.R., Arora, V.K., Prihar, S.S. 1992. Tillage management for efficient water and nitrogen use in wheat following rice. Soil and Tillage Res. 24:167-182.

López, M.V., Arrúe, J.L. 1997. Growth, yield and water use efficiency of winter barley in response to conservation tillage in a semi-arid region of Spain. Soil and Tillage Res. 44:35-54.

López-Bellido, R.J., López-Bellido, L. 2001. Efficiency of nitrogen in wheat under Mediterranean conditions: effect of tillage, crop rotation and $\mathrm{N}$ fertilization. Field Crops Res. 71:31-46.

Maich, R., Di Rienzo, J.A. 2014. Genotype $\times$ tillage interaction in a recurrent selection program in wheat. Cereal Res. Commun. 42:525-533.

Masle, J., Farquhar, G.D., Wong, S.C. 1992. Transpiration ratio and plant mineral content are related among genotypes of a range of species. Functional Plant Biol. 19:709-721.

Merah, O., Deléens, E., Monneveux, P. 1999. Grain yield, carbon isotope discrimination, mineral and silicon content in durum wheat under different precipitation regimes. Physiologia Plantarum 107:387-394.

Merah, O., Deléens, E., Monneveux, P. 2001. Relationships between carbon isotope discrimination, dry matter production, and harvest index in durum wheat. J. of Plant Physiol. 158:723-729.

Misra, S.C., Randive, R., Rao, V.S., Sheshshayee, M.S., Serraj, R., Monneveux, P. 2006. Relationship between carbon isotope discrimination, ash content and grain yield in wheat in the Peninsular Zone of India. J. of Agron. and Crop Sci. 192:352-362.

Misra, S.C., Shinde, S., Geerts, S., Rao, V.S., Monneveux, P. 2010. Can carbon isotope discrimination and ash content predict grain yield and water use efficiency in wheat? Agric. Water Management 97:57-65.

Monneveux, P., Rekika, D., Acevedo, E., Merah, O. 2006. Effect of drought on leaf gas exchange, carbon isotope discrimination, transpiration efficiency and productivity in field grown durum wheat genotypes. Plant Sci. 170:867-872.

Monneveux, P., Reynolds, M.P., González- Santoyo, H., Peña, R.J., Mayr, L., Zapata, F. 2004a. Relationships between grain yield, flag leaf morphology, carbon isotope discrimination and ash content in irrigated wheat. J. of Agron. and Crop Sci. 190:395-401.

Monneveux, P., Reynolds, M.P., Trethowan, R., Peña, J., Zapata, F. 2004b. Carbon isotope discrimination, leaf ash content and grain yield in bread and durum wheat grown under full-irrigated conditions. J. of Agron. and Crop Sci. 190:389-394.

O'Leary, G.J., Connor, D.J. 1997. Stubble retention and tillage in a semi-arid environment: 3 . Response of wheat. Field Crops Res. 54:39-50.

Pribyl, D.W. 2010. A critical review of the conventional SOC to SOM conversion factor. Geoderma 156:75-83.

Sadras, V.O., Connor, D.J. 1991. Physiological basis of the response of harvest index to the fraction of water transpired after anthesis: a simple model to estimate harvest index for determinate species. Field Crops Res. 26:227-239.

Zhang, X., Chen, S., Sun, H., Pei, D., Wang, Y. 2008. Dry matter, harvest index, grain yield and water use efficiency as affected by water supply in winter wheat. Irrigation Sci. 27:1-10.

Zhang, X., Chen, S., Sun, H., Wang, Y., Shao, L. 2010. Water use efficiency and associated traits in winter wheat cultivars in the North China Plain. Agric. Water Management 97:1117-1125.

Zhu, L., Liang, Z.S., Xu, X., Li, S.H. 2008. Relationship between carbon isotope discrimination and mineral content in wheat grown under three different water regimes. J. of Agron. and Crop Sci. 194:421-428.

Zhu, L., Liang, Z.S., Xu, X., Li, S.H., Monneveux, P. 2009. Evidences for the association between carbon isotope discrimination and grain yield-ash content and stem carbohydrate in spring wheat grown in Ningxia (Northwest China). Plant Sci. 176:758-767. 